\title{
Regeneration Responses in Partially-Harvested Riparian Management Zones in Northern Minnesota
}

\author{
Douglas N. Kastendick ${ }^{1}$, Brian J. Palik¹, Eric K. Zenner ${ }^{2}$, Randy K. Kolka ${ }^{1}$, Charles R. Blinn ${ }^{3}$, \\ Joshua J. Kragthorpe ${ }^{1}$ \\ ${ }^{1}$ USDA Forest Service, Northern Research Station, Grand Rapids, USA \\ ${ }^{2}$ Penn State University, University Park, USA \\ ${ }^{3}$ University of Minnesota, St. Paul, USA \\ Email: “dkastendick@fs.fed.us, bpalik@fs.fed.us, eric.zenner@psu.edu, rkolka@fs.fed.us, cblinn@umn.edu, \\ jkragthorpe@fs.fed.us
}

Received 22 January 2014; revised 21 February 2014; accepted 14 March 2014

Copyright (C) 2014 by authors and Scientific Research Publishing Inc.

This work is licensed under the Creative Commons Attribution International License (CC BY).

http://creativecommons.org/licenses/by/4.0/

(c) (i) Open Access

\section{Abstract}

Trees serve important functions in riparian areas. Guidelines often suggest how riparian forests should be managed to sustain functions, including tree retention and increasing the component of conifers and later-successional species. While regeneration of early successional species is not discouraged, there is uncertainty about the ability to regenerate the latter along with more desirable species. We investigated the regeneration of species differing in successional status and growth forms under different amounts of residual basal area. The study was conducted in riparian sites in northern Minnesota USA. At each site, one portion of the riparian area was uncut, while a downstream area was harvested to 16 or $8 \mathrm{~m}^{2} \cdot \mathrm{ha}^{-1}$. Woody vegetation was sampled before and five-years after harvesting and summarized as early, mid-, and late successional hardwoods, as well as conifers and shrubs. After five years, the density of early successional trees was lower at 16 $\mathrm{m}^{2} \cdot \mathrm{ha}^{-1}$ compared to $8 \mathrm{~m}^{2} \cdot \mathrm{ha}^{-1}$; densities in both treatments were lower than in clearcuts. Densities of mid- and late successional hardwoods and conifers did not increase in either treatment. The higher basal area treatment resulted in a lower density of shrubs, which might be important for establishing more desirable tree species, although this may require additional activities to promote establishment.

\section{Keywords}

Riparian Management, Overstory Retention, Regeneration, RMZ, Riparian Forest

\footnotetext{
${ }^{*}$ Corresponding author.

How to cite this paper: Kastendick, D.N., et al. (2014) Regeneration Responses in Partially-Harvested Riparian Management Zones in Northern Minnesota. Journal of Water Resource and Protection, 6, 556-564. 


\section{Introduction}

Trees in riparian areas serve many important ecological functions, including shading of streams, bank stabilization and protection from erosion, interception and uptake of water and nutrients from the upland [1]-[4]. Additionally, riparian trees contribute energy in the form of particulate and dissolved organic matter to aquatic systems [5] and they are the future source of coarse woody debris in streams and lakes [6]. Riparian forests are important habitat for species that are dependent on forests in close proximity to water [7] [8].

Many organizations and agencies have guidelines on how riparian forests should be managed to sustain ecological functions [9] [10]. Typically, these guidelines stress retention of trees in the riparian management zone (RMZ) and provide recommendations about minimum basal areas to be retained during harvesting. Also, guidelines often recommend sustaining or enhancing the abundance of conifers and longer-lived, often later successsional, hardwood species [9]. The greater longevity of conifers and later successional hardwoods compared to early successional species provides for greater continuity of riparian function and larger potential tree sizes, resulting in higher inputs of coarse woody debris into aquatic habitats in the long run.

While management guidelines generally do not discourage silvicultural activities in riparian areas, managers may nevertheless forego harvests in RMZs because of uncertainties about the ability to regenerate desirable tree species (i.e., conifers, later successional species) and the ability to maintain riparian functions that are dependent on trees [11]. There have been only a few experimental studies that have examined regeneration responses to partial harvesting treatments of RMZs within the context of riparian management guidelines that aim to sustain tree-derived functions and increase the component of more desirable tree species [e.g. [12] [13]].

Here we experimentally investigated the regeneration response to partial harvesting treatments in riparian areas that prescribed different levels of residual basal area within fixed-width RMZs. Specifically, we investigated how species of differing successional status (early, mid-, late) and growth forms (conifers, hardwoods, shrubs) regenerated under residual basal areas of $16 \mathrm{~m}^{2} \cdot \mathrm{ha}^{-1}$ and $8 \mathrm{~m}^{2} \cdot \mathrm{ha}^{-1}$. This experiment was conducted in mature mixed-species riparian forests dominated by early successional species, including trembling aspen (Populus tremuloides) and paper birch (Betula papyrifera) and a smaller component of conifers and later successsional hardwoods. Our applied goal was to provide managers with information about approaches for managing similar riparian areas in ways that might reduce the density of early successional species and increase the abundance of later successional and conifer species.

\section{Materials and Methods}

\subsection{Study Area}

This study was conducted in eight forested riparian areas in the Laurentian Mixed Forest Province of Minnesota. The province is as a broad ecotone between the eastern deciduous forest and boreal forest biomes. It has a temperate climate with mean annual temperatures between $1.1^{\circ} \mathrm{C}$ and $3.9^{\circ} \mathrm{C}$, and average annual precipitation between 56 and $81 \mathrm{~cm}$ [14]. Soils originated from Pleistocene till [15] and include well drained loamy sands that are shallow to bedrock in the uplands and sandy loams in lower landscape positions.

The eight study sites were selected in 2003 to meet the following criteria: 1) riparian forests were located adjacent to perennial streams that were less than $6 \mathrm{~m}$ in width; 2) a minimum contiguous forested area of 6.5 ha with a minimum of $183 \mathrm{~m}$ of stream frontage; 3 ) forests were mature and well-stocked in both the riparian zones and adjacent uplands.

Prior to treatment, dominant tree species included paper birch, trembling aspen, balsam fir (Abies balsamea), black ash (Fraxinus nigra), sugar maple (Acer saccharum), red maple (Acer rubrum), and basswood (Tilia americana), with lesser amounts of northern red oak (Quercus rubra), bur oak (Quercus macrocarpa), green ash (Fraxinus pennsylvanica), white spruce (Picea glauca), black spruce (Picea mariana), big-tooth aspen (Populus grandidentata), balsam poplar (Populus balsamifera), yellow birch (Betula allegheniensis), silver maple (Acer saccharinum), ironwood (Ostrya virginiana), and northern white cedar (Thuja occidentalis). Collectively, early successional species (paper birch, trembling aspen, big-tooth aspen, and balsam poplar) comprised around $52 \%$ of the total basal area.

\subsection{Experimental Design and Treatments}

At each study site (sites treated as blocks for statistical analysis), two 3.2 ha treatment stands were delineated on 
one side of the stream, with the two stands separated by at least $61 \mathrm{~m}$ of unharvested forest (Figure 1). Within each treatment stand, a 0.8 ha riparian management zone (RMZ) was delineated along the length of the stream $(183 \mathrm{~m})$ that extended $46 \mathrm{~m}$ towards the upland, a width that corresponds to recommended RMZ widths for even-age management in the state of Minnesota [16]. The remainder of the treatment unit (2.4 ha) was outside of the RMZ and considered to be upland forest.

In each block, the following treatments were assigned to the two experimental units: 1) upland clearcut-RMZ uncut (RMZC) and 2) upland clearcut-RMZ partially harvested (RMZH) to a residual basal area of $16 \mathrm{~m}^{2} \cdot \mathrm{ha}^{-1}$ (33\% reduction) or 3) upland clearcut-RMZ partially harvested (RMZL) to a residual basal area of $8 \mathrm{~m}^{2} \cdot \mathrm{ha}^{-1}(66 \%$ reduction). Only one of the two RMZ harvest treatments was assigned to each block due to space constraints; the result was an incomplete block design (see Statistical Analysis). To lessen confounding impacts of harvesting on streams, the RMZC treatment was always established upstream of the RMZH or RMZL treatments. The tree retention levels tested in this study fell within the range of residual basal area values recommended for RMZs in Minnesota [16]. Marking of residual trees followed riparian guidelines for Minnesota by reserving, where possible, longer-lived species, conifers, and hard mast-producing species.

Timber harvesting operations were conducted by experienced operators on frozen ground when sufficient snow had accumulated during the winter of 2003-2004 using conventional harvesting equipment (i.e., fellerbuncher and grapple skidder).

\subsection{Vegetation Sampling}

In each stand, five transects were established running perpendicular to the average stream meander, originating at the stream bankfull edge and terminating in the upland (Figure 1). Five vegetation measurement plots were established on each transect; four plots (each $4.6 \mathrm{~m}$ wide by $7.6 \mathrm{~m}$ long $=34.8 \mathrm{~m}^{2}$ ) located in the RMZ and one plot located in the upland area outside of the RMZ (Figure 1). The first RMZ plot was established at the stream bankfull edge. The distance between the remaining RMZ plots varied because plots were constrained to be centered within major geomorphic features (i.e., floodplain, terrace, hillslope), but generally the second RMZ plot was $9.1 \mathrm{~m}$. from the stream, while the third plot was $22.9 \mathrm{~m}$. from the stream. The fourth RMZ plot was always located $3 \mathrm{~m}$. inside of the RMZ-upland boundary. The upland plot was always established $22.9 \mathrm{~m}$. outside of the RMZ-upland boundary. Each treatment unit contained a total of 25 plots ( 5 transects $\times 5$ plots).

Woody vegetation was sampled using a nested plot design. Species and diameter at $1.4 \mathrm{~m}$ (breast height $=\mathrm{dbh}$ ) of trees $(\mathrm{dbh} \geq 12.7 \mathrm{~cm})$ and saplings $(2.5 \leq \mathrm{dbh}<12.7 \mathrm{~cm})$ were sampled in the $4.6 \mathrm{~m} \times 7.6 \mathrm{~m}$ plots. Woody stems (shrub species and advance tree regeneration) with $\mathrm{dbh}<2.5 \mathrm{~cm}$ but $\geq 0.8 \mathrm{~m}$ tall were sampled in two 0.6 $\mathrm{m} \times 4.6 \mathrm{~m}\left(2.8 \mathrm{~m}^{2}\right)$ plots nested within ends of the larger overstory plot. Small woody stems $(<0.8 \mathrm{~m}$ tall $)$ were tallied in six $0.6 \mathrm{~m} \times 0.6 \mathrm{~m}\left(0.36 \mathrm{~m}^{2}\right)$ regeneration plots nested within each of the $2.8 \mathrm{~m}^{2}$ plots. Vegetation was measured in the summer before harvesting and again five years after the harvest, after the majority of the growing season had elapsed, but prior to leaf senescence.

\subsection{Statistical Analysis}

Due to the variation in composition among the eight study blocks and to facilitate statistical analyses, we com-

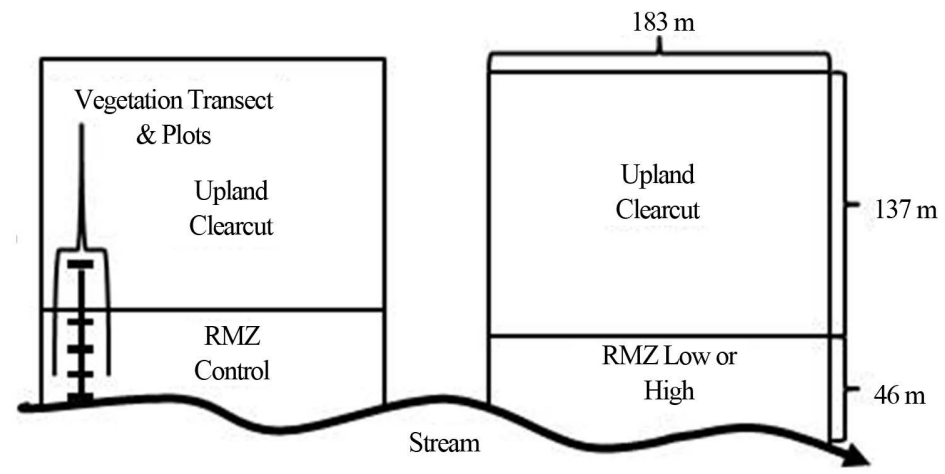

Figure 1. Study site layout illustrating treatment unit dimensions and vegetation sampling plot layout. 
bined species into broader groups that reflected successional status and growth form. Groups included early successional hardwoods (paper birch, trembling aspen, big-tooth aspen, balsam poplar), mid-successional hardwoods (black ash, northern red oak, bur oak, green ash, silver maple, yellow birch, and American elm), late successional hardwoods (sugar maple, red maple, basswood, ironwood), and conifers (balsam fir, white spruce, black spruce, northern white cedar). Woody shrubs included mountain maple (Acer spicatum), alder (Alnus spp.), serviceberry (Amelanchier spp.), dogwood (Cornus alternifolia, Cornus sericea), hazel (Corylus americana, Corylus cornuta), honeysuckle (Lonicera spp.), cherry (Prunus pensylvanica, Prunus virginiana), and willow (Salix spp.). We summarized changes (between pre-harvest and $5^{\text {th }}$ year post-harvest) in the proportional contribution to total density (in the sapling and regeneration layers) of each of these broad species groups (early, mid-, late successional, conifers, shrubs). For example, early successional hardwoods might have contributed $20 \%$ to total sapling density before harvest, but $60 \%$ after harvest, for a change of $+40 \%$.

Differences among treatments in basal area and stem density were assessed using an incomplete block mixed-model ANOVA with eight replicates for the control treatment (RMZC) and four replicates each for the riparian harvest treatments (RMZH, RMZL). Block was the random effect and basal area was the fixed effect. Pre- and post-harvest responses were analyzed separately. Some variables, including pre-harvest late successsional regeneration, $5^{\text {th }}$ year early successional saplings, mid-successional trees, mid-successional saplings, late successional saplings, and regeneration were square-root transformed to meet the assumption of normality and homogeneity of variances. An alpha level of $\leq 0.05$ was considered statistically significant. Statistically significant models were further investigated using a set of orthogonal contrasts that compared 1) the RMZCs to the pooled partial harvesting treatments and 2) the RMZHs to the RMZLs. All statistical analyses were conducted using SAS 8.02 [17]. For comparative purposes, we included data from the adjacent upland clearcuts in the results, but we did not include these data in the statistical analyses because the upland clearcut treatment was confounded with location in our design.

\section{Results}

\subsection{Tree Layer}

Mean pre-harvest basal area was $23.7 \mathrm{~m}^{2} \cdot \mathrm{ha}^{-1}$ and did not differ statistically among the (future) RMZ treatments ( $>0.05$; Table 1). Densities of early, mid- and late successional hardwood species, as well as conifers and total density, were not significantly different among treatments before harvest. Five years after harvest, residual basal areas reflected the harvest intensity gradient from the RMZC to the RMZL treatments (Table 1). Additionally, there was a statistically significant difference among treatments in total tree density $(p=0.025)$, with higher densities in the RMZCs than in the pooled harvest treatments ( $=0.01)$, but no significant differences between the two RMZ treatments ( $p>0.05$ ). There were trends in densities among treatments for all species groups that largely paralleled the gradient in basal area reduction (Table 1); however, due to high variation, these densities were not statistically different among the treatments. As expected, tree densities for all groups of trees and total density were substantially lower in the adjacent clearcuts than in the RMZ treatments.

\subsection{Sapling Layer}

Before harvest, total sapling density, as well as densities of hardwoods, conifers, and woody shrubs (that were large enough to be classified as saplings) did not differ statistically among (future) treatments (Figure 2(a)). Five years after harvest, total density of saplings did not differ among treatments, but there were differences among treatments in early successional hardwoods $(p=0.03$; Figure 2(b)), with higher density in the RMZL compared to the RMZH treatment $(\mathrm{p}=0.012)$. Moreover, early successional hardwood densities were higher in the clearcut uplands than either of the RMZ harvest treatments. The change in proportional contribution to total sapling density of early successional hardwoods after five years was small $(< \pm 5 \%)$ in the RMZC and RMZH treatments, but was high and positive in the RMZL treatment (+13\%) and the clearcut uplands $(+56 \%)$, reflecting the substantial increases in sapling density of this group in these treatments (Table 2).

Densities of mid- and late successional hardwoods declined from the control to the RMZL treatment (Figure 2(b)), but the differences among treatments were not statistically significant. Proportional contribution to total sapling density of these groups did not change appreciably $(\leq \pm 5 \%)$ by five years after harvest (Table 2$)$.

Conifer densities were not statistically different among RMZ treatments (Figure 2(b)) and changes in proportional contribution to total sapling density were low $(< \pm 5 \%)$. In contrast, the proportional contribution of 
Table 1. Tree layer ${ }^{\mathrm{a}}$ characteristics in riparian management zone treatments.

\begin{tabular}{|c|c|c|c|c|c|c|c|c|}
\hline & \multicolumn{3}{|c|}{ Pre-Harvest } & \multicolumn{3}{|c|}{ Post-Harvest (5 years) } & \multicolumn{2}{|c|}{ Upland Clearcut } \\
\hline & RMZC $^{\mathrm{b}}$ & $\mathrm{RMZH}^{\mathrm{c}}$ & RMZL $^{\mathrm{d}}$ & RMZC & RMZH & RMZL & Pre & Post \\
\hline Basal Area $\left(\mathrm{m}^{2} \cdot \mathrm{ha}^{-1}\right)$ & $23.9(1.8)^{\mathrm{e}}$ & 25.7 (3.9) & $21.6(4.6)$ & $23.7(2.1)$ & $15.6(2.5)$ & $8.0(1.6)$ & $23.9(2.5)$ & $1.1(0.5)$ \\
\hline Total Density (stems $\cdot \mathrm{ha}^{-1}$ ) & 1486 (114) & $1463(161)$ & 1366 (116) & $1431(163)$ & 877 (156) & $576(183)$ & 1463 (109) & 185 (69) \\
\hline $\begin{array}{l}\text { Early Successional }{ }^{f} \\
\text { Density }\left(\text { stems } \cdot \mathrm{ha}^{-1} \text { ) }\right.\end{array}$ & $613(119)$ & $675(217)$ & $682(185)$ & $536(126)$ & $284(124)$ & 213 (116) & $771(143)$ & $62(35)$ \\
\hline $\begin{array}{l}\text { Mid-Successional } \\
\text { Density (stems } \text { ha }^{-1} \text { ) }\end{array}$ & $284(163)$ & $274(252)$ & $106(72)$ & $274(158)$ & 222 (198) & $62(22)$ & $96(49)$ & $35(27)$ \\
\hline $\begin{array}{l}\text { Late Successional }{ }^{\mathrm{h}} \\
\text { Density }\left(\text { stems } \cdot \mathrm{ha}^{-2} \text { ) }\right.\end{array}$ & $195(91)$ & $195(104)$ & $222(222)$ & $213(101)$ & $161(82)$ & $62(42)$ & $292(148)$ & $0(0)$ \\
\hline Conifers ${ }^{\mathrm{i}}\left(\right.$ stems $\cdot \mathrm{ha}^{-1}$ ) & 395 (126) & 319 (156) & 356 (193) & 408 (158) & $213(104)$ & 240 (124) & $301(96)$ & $89(47)$ \\
\hline
\end{tabular}

${ }^{\mathrm{a}}$ Diameter at $1.4 \mathrm{~m} \geq 12.7 \mathrm{~cm}$; ${ }^{\mathrm{b}} \mathrm{RMZC}=$ uncut (control) RMZ; ${ }^{\mathrm{C}} \mathrm{RMZH}=\mathrm{RMZ}$ cut to $16 \mathrm{~m}^{2} \cdot \mathrm{ha}^{-1}$; ${ }^{\mathrm{d}} \mathrm{RMZL}=\mathrm{RMZ}$ cut to $8 \mathrm{~m}^{2} \cdot \mathrm{ha}^{-1}$; ${ }^{\mathrm{e}} \mathrm{Means} \pm 1 \mathrm{stan}-$ dard error; ${ }^{\mathrm{f}}$ Early successional includes paper birch, trembling aspen, big-tooth aspen, and balsam poplar; ${ }^{\mathrm{g}}$ Mid-successional includes black ash, green ash, northern red oak, bur oak, silver maple, yellow birch, and American elm; ${ }^{h}$ Late successional includes sugar maple, red maple, basswood, and

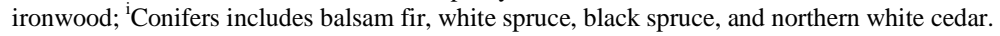

conifers to total sapling density declined by nearly 19\% in the clearcut (Table 2). Woody shrub densities were reduced by harvest (Figure 2(b)), although they did not differ statistically among RMZ treatments. Densities were lower in the upland clearcuts compared to the RMZ treatments. Proportional contribution of shrubs to total sapling density declined in all treatments. The decline was small (-3.9\%) in the RMZC treatment (Table 2), but larger in the other RMZ treatments $(-11.3 \%$ in RMZH; $-15.9 \%$ in RMZL) and the upland clearcut $(-29.7 \%)$.

\subsection{Regeneration Layer}

Densities of hardwood groups were low before harvest and did not differ statistically among (future) treatments (Figure 3(a)). Densities of conifers and woody shrubs were higher than those of hardwoods, but were variable and their densities, as well as total regeneration density, did not differ statistically among (future) treatments. Five years after harvest, total density in the regeneration layer differed statistically among treatments $(p=0.04)$, with higher densities in the pooled harvest treatments compared to the RMZC treatment $(p=0.03)$, but no statistical difference between the two partially harvested RMZ treatments. Densities of early successional hardwoods after harvest differed statistically among treatments $(\mathrm{p}<0.001$; Figure $3(\mathrm{~b})$ ), with higher densities in the pooled harvest treatments compared to the RMZC treatment $(p=0.002)$ and higher densities in the RMZL compared to the RMZH treatment $(\mathrm{p}=0.03)$. Densities in the clearcut uplands were substantial higher than in the partially harvested RMZ treatments. Change in proportional contribution of early successional hardwoods to total regeneration density was positive for all treatments (Table 2 ), but not particularly high $(<+5.4 \%$ ), indicating that the relative densities of this group were not substantially changed by year five, mostly because sucker stems had grown into the sapling layer by this time.

Densities of mid- and late-successional hardwoods did not differ statistically among treatment five years after harvest and were similar to pre-harvest levels, with small changes in proportional contribution to total density (< $\pm 5.3 \%$ ), with the exception of late successional hardwoods in the RMZH treatment, which were substantially reduced (-11.9\%). Conifer densities were reduced from pre-harvest levels in all treatments, including a $24 \%$ $46 \%$ reduction in proportional contribution to total density (Table 2), but densities did not differ significantly among treatments.

Woody shrub densities differed among treatments five years after harvest (Figure 3(b)), with densities in the pooled harvest treatments statistically higher than in the RMZC treatment $(p=0.03)$ and densities in the RMZL treatment higher than in the RMZH treatment $(p=0.04)$. A commensurate large increase $(21.1 \%$ to $40.6 \%)$ in the proportional contribution of shrubs to total regeneration density was observed in all treatments (Table 2).

\section{Discussion}

An important question for forest managers is how to balance extracting timber from riparian areas with sustaining riparian functions that depend on the regeneration of desirable tree species and species groups (e.g., con- 

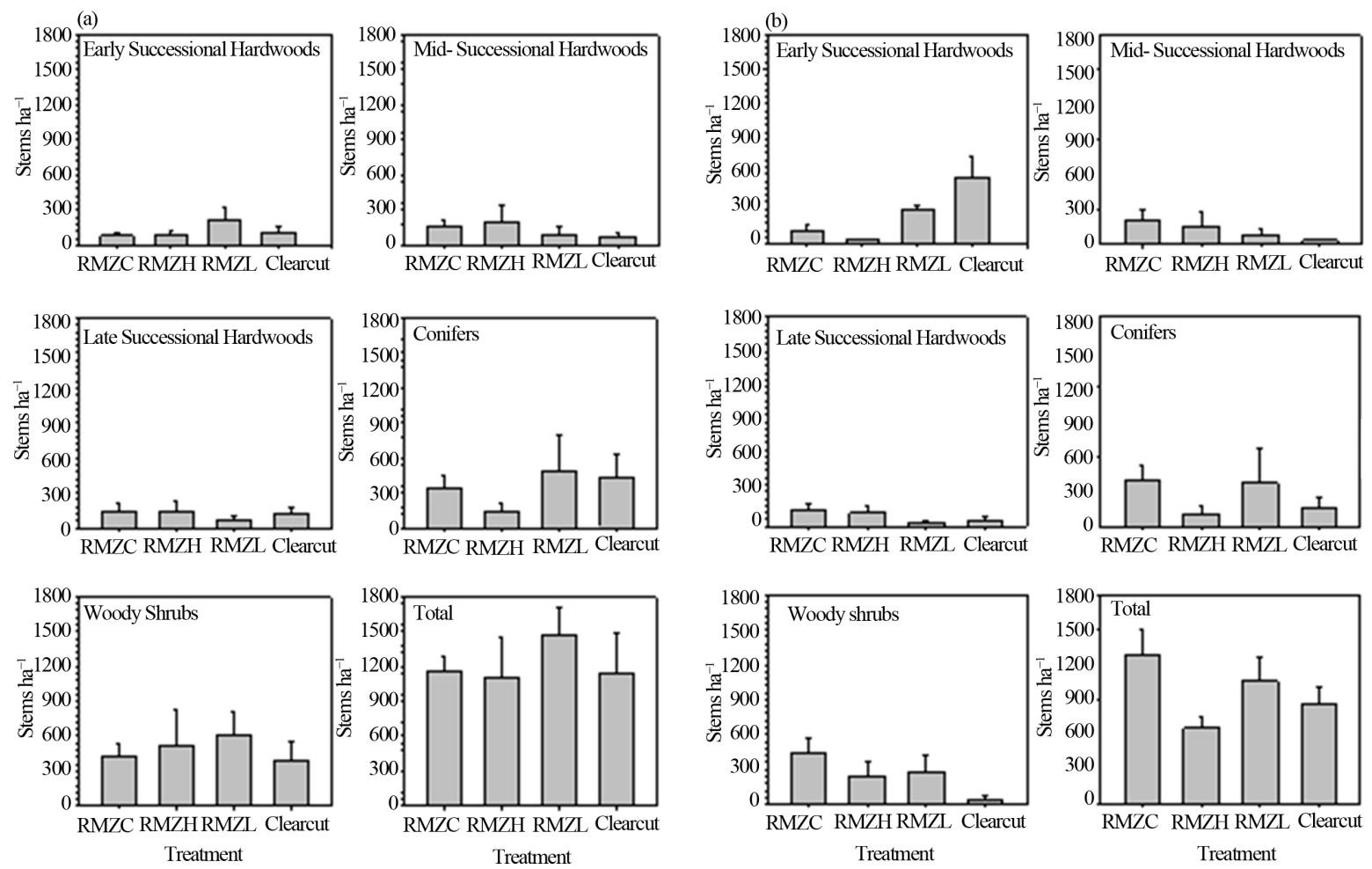

Figure 2. Sapling $(2.5<\mathrm{dbh}<12.5 \mathrm{~cm})$ densities of species groups before harvest (a) and five years after harvest (b) See text for explanation of treatments and species groups.

Table 2. Change (from pre-harvest to five years after harvest) in proportional contribution to total density of different successional classes and growth forms in the different treatments.

\begin{tabular}{ccccccccccc}
\hline Treatment $^{\mathrm{a}}$ & \multicolumn{3}{c}{ Sapling Layer } & \multicolumn{5}{c}{ Regeneration Layer } \\
& Early $^{\mathrm{b}}$ & Mid- $^{\mathrm{c}}$ & Late $^{\mathrm{d}}$ & Conifers $^{\mathrm{e}}$ & Shrubs $^{\mathrm{f}}$ & Early & Mid- & Late & Conifers & Shrubs \\
\hline RMZC & 1.9 & 2.4 & -2.0 & 1.6 & -3.9 & 1.4 & 5.3 & 3.9 & -31.9 & 21.1 \\
RMZH & -3.0 & 4.8 & 4.6 & 4.8 & -11.3 & 3.7 & 1.9 & -11.9 & -23.9 & 30.1 \\
RMZL & 13.2 & 1.3 & -1.1 & 2.5 & -15.9 & 3.7 & 1.7 & 0.5 & -45.9 & 40.0 \\
Upland & & & & & & & & & & \\
Clearcut & 56.1 & -2.6 & -5.2 & -18.6 & -29.7 & 5.4 & -0.9 & -5.1 & -40.1 & 40.6 \\
\hline
\end{tabular}

${ }^{\mathrm{a}} \mathrm{RMZC}=$ uncut (control) RMZ; RMZH = RMZ cut to $16 \mathrm{~m}^{2} \cdot \mathrm{ha}^{-1}$; RMZL $=$ RMZ cut to $8 \mathrm{~m}^{2} \cdot \mathrm{ha}^{-1}$. ${ }^{\mathrm{b}}$ Early successional includes paper birch, trembling aspen, big-tooth aspen, and balsam poplar. ${ }^{\circ}$ Mid-successional includes black ash, northern red oak, bur oak, green ash, silver maple, yellow birch, and American elm. ${ }^{\mathrm{d}}$ Late successional includes sugar maple, red maple, basswood, and ironwood. ${ }^{e}$ Conifers includes balsam fir, white spruce, black spruce, and northern white cedar. ${ }^{f}$ Shrubs include the woody species mountain maple, speckled alder, serviceberry, dogwood, honeysuckle, cherry, willow, and hazel species.

ifers, later successional species). This is particularly important in the water-rich Great Lakes regional landscape where a high percentage of the forest is riparian. For example, one estimate indicates that $37 \%$ of commercial forests in Minnesota are within $57 \mathrm{~m}$ of surface water [18], a distance that places the bulk of this forest within Minnesota's recommended RMZ width guideline of $46 \mathrm{~m}$ [16]. Consequently, a management objective for a mixed riparian forest like the one we examined will likely include managing for timber but in ways that: 1) reduce the density of early successional species, which in the Lake States often includes aspen and birch; and 2) regenerating and enhancing the proportion of longer lived, late-successional hardwoods and conifers.

The partial harvest treatments in the RMZs we examined were successful at meeting the first part of this ob- 


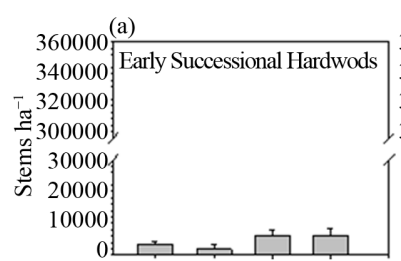

RMZC RMZHRMZL Clearcut

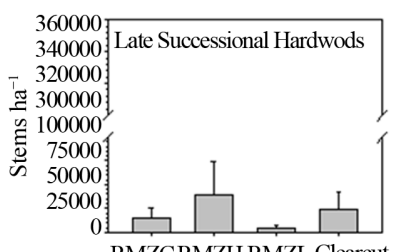

RMZCRMZH RMZI Clearcut

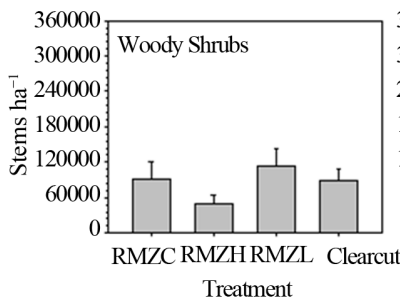

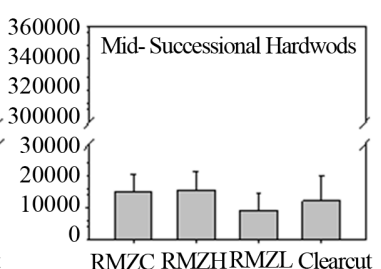
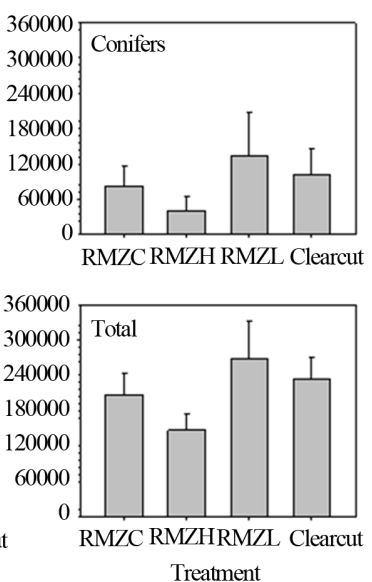
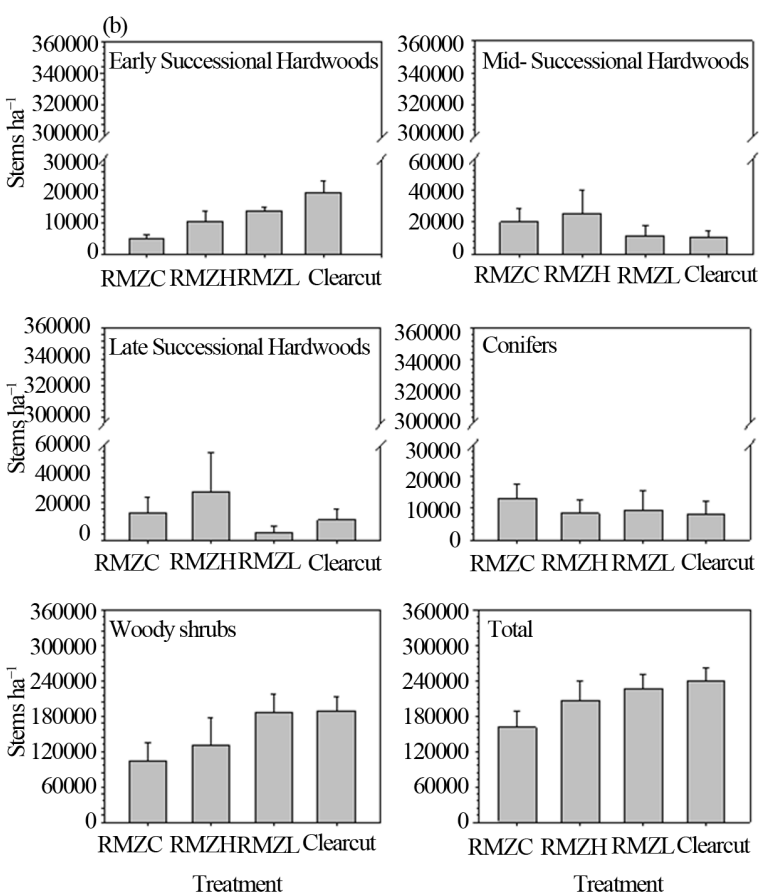

Figure 3. Regeneration ( $\mathrm{dbh}<2.5 \mathrm{~cm}$ ) densities of species groups before harvest (a) and five years after harvest (b) See text for explanation of treatments and species groups.

jective. While early results ( 1 and 3 years after harvest) indicated that aspen sucker densities in the RMZs were within the range of acceptable stocking [13], after five years, this stocking had declined to levels that were less than one-third the stocking densities for aspen in similar aged clearcut stands [19] [20] and much less than the densities in the adjacent clearcuts we examined, especially in the RMZH treatment. While the density of early successional taxa did increase in parallel with the decreasing basal area of residual trees (from RMZC to RMZL), and the proportional composition of total sapling density for aspen and birch increased by $13.2 \%$ in the RMZL treatment, these relatively low basal areas still apparently checked sucker and seedling establishment or survival, relative to clearcuts, similar to findings from other studies [21]-[23].

The second part of the management objective, that of enhancing the abundance of later successional hardwoods and conifers, was largely not accomplished. Despite reserving mid- and later successional hardwood species and conifers as future seed sources in the overstory, these species were not able to capitalize (at least in the first 5 years) on the reduced density of early successional hardwoods. In fact, the proportional contribution to total regeneration density of conifers declined substantially in all RMZ treatments, including the controls, with a particularly strong decline in the RMZL treatment. We hypothesize that increases in solar radiation and temperature, which may have affected conifers even in the controls through edge effects [24] [25], may have caused moisture stress and mortality in spruce and fir seedlings [26] [27].

The increase in proportional contribution of woody shrubs, mainly beaked hazel and mountain maple, to total density in the regeneration layer of all RMZ treatments, and particularly in the RMZL treatment, may have further contributed to the limited regeneration success of trees. Resource preemption by a woody understory layer [28]-[30], and beaked hazel in particular [31], is recognized as a deterrent to the regeneration of trees. Thus the response of shrubs to harvesting in this study may have restricted the establishment of new trees and/or the growth of seedlings into the sapling size class. This inhibition appears to have been somewhat less in the RMZH compared to RMZL treatment.

While our treatments did not result in significant increases in densities of trees species deemed especially desirable in riparian settings (mid- and later successional hardwoods, conifers), our results do point to some practical guidance to managers working in such settings. First, leaving a residual basal area of $16 \mathrm{~m}^{2} \cdot \mathrm{ha}^{-1}$, as we did in our RMZH treatment, was effective at limiting the regeneration density of early successional species (mostly aspen) to a greater degree than $8 \mathrm{~m}^{2} \cdot \mathrm{ha}^{-1}$ in the RMZL treatment. Ultimately this reduction should be important for creating greater opportunities for establishment and growth of the other species groups. Secondly, although 
the density of sapling-sized woody shrubs declined following treatment, woody shrub density increased substantially in the regeneration layer. The increased abundance of these keen competitors may be an obstacle to the establishment, survival, and growth of more desirable tree species in riparian areas. This combination of responses-suppression of early successional species and expansion of woody shrubs, suggests the need for additional activities to promote regeneration of mid- and later successional hardwoods and conifers. In particular, competition control to reduce shrub densities [12] [13], along with seeding or planting of desired species, may be needed to ensure regeneration success.

\section{Acknowledgements}

The authors thank Dwight Streblow, Adam Sutherland, and Jeff Killmer for logistical and field support, the USDA Forest Service Northern Research Station, the University of Minnesota, Department of Forest Resources, and the Minnesota Environment and Natural Resources Trust Fund for financial support.

\section{References}

[1] Kreutzweiser, D.P. and Capell, S.S. (2001) Fine Sediment Deposition in Streams after Selective Forest Harvesting without Riparian Buffers. Canadian Journal of Forest Research, 31, 2134-2142. http://dx.doi.org/10.1139/x01-155

[2] Broadmeadow, S. and Nisbet, T.R. (2004) The Effects of Riparian Forest Management on the Freshwater Environment: A Literature Review of Best Management Practices. Hydrology and Earth System Science, 8, 286-305. http://dx.doi.org/10.5194/hess-8-286-2004

[3] Hazlett, P.W., Gordon, A.M., Voroney, R.P. and Sibley, P.K. (2007) Impact of Harvesting and Logging Slash on Nitrogen and Carbon Dynamics in Soils from Upland Spruce Forests in Northeastern Ontario. Soil Biology and Biochemistry, 39, 43-57. http://dx.doi.org/10.1016/j.soilbio.2006.06.008

[4] Kastendick, D.N., Zenner, E.K., Palik, B.J., Kolka, R.K. and Blinn, C.R. (2012) Effects of Harvesting on Nitrogen and Phosphorus Availability in Riparian Management Zone Soils in Minnesota, USA. Canadian Journal of Forest Research, 42, 1784-1791. http://dx.doi.org/10.1139/x2012-127

[5] Naiman, R.J., Bilby, R.E. and Bisson, P.A. (2000) Riparian Ecology and Management in Pacific Coastal Rain Forest. BioScience, 50, 996-1011. http://dx.doi.org/10.1641/0006-3568(2000)050[0996:REAMIT]2.0.CO;2

[6] Palik, B.J., Golladay, S.W., Goebel, P.C. and Taylor, B.W. (1998) Geomorphic Variation in Riparian Tree Mortality and Stream Coarse Woody Debris Recruitment from Record Flooding in a Coastal Plain Stream. Ecoscience, 5, 551560 .

[7] Hannon, S.J., Paszkowski, C.A., Boutin, S., DeGroot, J., Macdonald, S.E., Wheatley, M. and Eaton, B.R. (2002) Abundance and Species Composition of Amphibians, Small Mammals, and Songbirds in Riparian Forest Buffer Strips of Varying Widths in the Boreal Mixedwood of Alberta. Canadian Journal of Forest Research, 32, 1784-1800. http://dx.doi.org/10.1139/x02-092

[8] Goebel, C.P., Palik, B.J. and Pregitzer, K.S. (2003) Plant Diversity Contributions of Riparian Areas in Watersheds of the Northern Lake States, USA. Ecological Applications, 13, 1595-1609. http://dx.doi.org/10.1890/01-5314

[9] Blinn, C.R. and Kilgore, M.A. (2001) Riparian Management Practices: A Summary of State Guidelines. Journal of Forestry, 99, 11-17.

[10] Wisconsin Department of Natural Resources (2011) Chapter 5: Riparian Areas and Wetlands. Pub-FR-226, Madison.

[11] Palik, B.J., Zasada, J.C. and Hedman, C.W. (2000) Ecological Principles for Riparian Silviculture. In: Verry, E.S., Hornbeck, J.W. and Dolloff, C.A., Eds., Riparian Management in Forests of the Continental Eastern United States, Lewis Publishers, Boca Raton, 233-254.

[12] Palik, B., Martin, M., Zenner, E., Blinn, C. and Kolka, R. (2012) Overstory and Regeneration Dynamics in Riparian Management Zones of Northern Minnesota Forested Watersheds. Forest Ecology and Management, 271, 1-9. http://dx.doi.org/10.1016/j.foreco.2012.01.045

[13] Zenner, E.K., Olszewski, S.L., Palik, B.J., Kastendick, D.N., Peck, J.E. and Blinn, C.R. (2012) Riparian Vegetation Response to Gradients in Residual Basal Area with Harvesting Treatment and Distance to Stream. Forest Ecology and Management, 283, 66-76. http://dx.doi.org/10.1016/j.foreco.2012.07.010

[14] Minnesota Department of Natural Resources (2003) Field Guide to the Native Plant Communities of Minnesota: The Laurentian Mixed Forest Province. Ecological Land Classification Program, Minnesota County Biological Survey, and Natural Heritage and Nongame Research Program, St. Paul.

[15] Keys Jr., J.E., Carpenter, C.A., Hooks, S.L., Koeneg, F.G., McNab, W.H., Russell, W.E. and Smith, M.L. (1995) Ecological Units of the Eastern United States-First Approximation. USDA Forest Service Technical Publication, R8-TP 
21.

[16] Minnesota Forest Resources Council (1999) Sustaining Minnesota Forest Resources: Voluntary Site-Level Management Guidelines for Landowners, Loggers and Resource Managers. Minnesota Forest Resources Council, St. Paul.

[17] SAS (Statistical Analysis Systems Institute) (2002) SAS Ver. 8.02. SAS Institute, Cary.

[18] Hanowski, J., Danz, N., Lind, J., Niemi, G. and Wolter, P. (2001) Wildlife Species: Responses to Forest Harvesting and Management in Riparian Stands and Landscapes. Final Report to the Minnesota Forest Resources Council, St. Paul.

[19] Perala, D.A. (1979) Regeneration and Productivity of Aspen Grown on Repeated Short Rotations. USDA Forest Service Research Paper NC-176.

[20] Stone, D.M. and Elioff, J.D. (1998) Soil Properties and Aspen Development Five Years after Compaction and Forest Floor Removal. Canadian Journal of Soil Science, 78, 51-58. http://dx.doi.org/10.4141/S97-026

[21] Huffman, R.D., Fajvan, M.A. and Wood, P.B. (1999) Effects of Residual Overstory on Aspen Development in Minnesota. Canadian Journal of Forest Research, 29, 284-289. http://dx.doi.org/10.1139/x98-202

[22] Stone, D.M., Elioff, J.D., Potter, D.V., Peterson, D.B. and Wagner, R. (2001) Restoration of Aspen-Dominated Ecosystems in the Lake States. In: Shepperd, W.D., Ed., Sustaining Aspen in Western Landscapes, USDA Forest Service General Technical Report RMRS-P-18, USDA, Forest Service, Rocky Mountain Research Station, 137-143.

[23] Palik, B.J., Cease, C. and Egeland, L. (2003) Aspen Regeneration in Riparian Management Zones in Northern Minnesota: Effects of Residual Overstory and Harvest Method. Northern Journal of Applied Forestry, 20, 79-84.

[24] Young, A. and Mitchell, N. (1994) Microclimate and Vegetation Edge Effects in a Fragmented Podocarp-Broadleaf Forest in New Zealand. Biological Conservation, 67, 63-72. http://dx.doi.org/10.1016/0006-3207(94)90010-8

[25] Chen, J., Franklin, J.F. and Spies, T.A. (1995) Growing-Season Microclimatic Gradients from Clearcut Edges into Old-Growth Douglas-Fir Forests. Ecological Applications, 5, 74-86. http://dx.doi.org/10.2307/1942053

[26] Thomas, P.A. and Wein, R.W. (1985) Water Availability and the Comparative Emergence of Four Conifer Species. Canadian Journal of Botany, 63, 1740-1746.

[27] Burns, R.M. and Honkala, B.H. (1990) Silvics of North America: 1. Conifers; 2. Hardwoods. US Department of Agriculture, Forest Service, Agriculture Handbook 654, Washington DC.

[28] Lorimer, C.G. Chapman, J.W. and Lambert, W.D. (1994) Tall Understory Vegetation as a Factor in the Poor Development of Oak Seedlings beneath Mature Stands. Journal of Ecology, 82, 227-237. http://dx.doi.org/10.2307/2261291

[29] Dovčiak, M., Frelich, P.B. and Reich, L.E. (2003) Seed Rain, Safe Sites, Competing Vegetation and Soil Resources Spatially Structure White Pine Regeneration and Recruitment. Canadian Journal of Forest Research, 33, 1892-1904. http://dx.doi.org/10.1139/x03-115

[30] Weyenberg, S., Frelich, P.B. and Reich, L.E. (2004) Logging Versus Fire: How Does Disturbance Type Influence the Abundance of Pinus strobus Regeneration. Silva Fennica, 38, 79-194.

[31] Kuuseoks, E., Dong, J. and Reed, D. (2001) Shrub Age Structure in Northern Minnesota Aspen Stands. Forest Ecology and Management, 149, 265-274. http://dx.doi.org/10.1016/S0378-1127(00)00559-4 